\title{
LEVEL BETA-CAROTENE AND VITAMIN A IN BLOOD SERUM OF PREGNANT AND HIGHLY LACTATING COWS FED WITH DIFFERENT COMPOSITIONS
}

\author{
Bisa Radović, Jasmina Janjić, Milinko Milenković, Boban Jašović, \\ Atanas Nitovski, Valentina Milanović \\ Agriculture Faculty, Lesak, Kosovo and Metohia, Serbia, \\ bisaradovic@yahoo.com
}

\begin{abstract}
The studies were conducted on the farm of Simmental cows where five groups of 12 cows were formed in which concentrations of beta-carotene and vitamin A in blood serum were tested. In the first group were highly pregnant cows, and in the other four groups were cows from the first to the fifth months of lactation. The composition of a meal of high pregnant and lactating cows in terms of the types and amounts of certain nutrients were different. In the obtained average values of beta - carotene in the blood serum of cows between the groups there was not statistically significant different. The lowest value of beta - carotene in relation to the other groups, was in the serum of the cows in the first month of lactation $(x=3,39 \pm 0,27 \mathrm{mmol} / \mathrm{l})$. The average concentration of vitamin A was statistically significantly lower in cows in the first month of lactation $(x=76,67 \pm 6,39 \mathrm{IU})$ compared to cows that were in the fourth $(x=112,03 \pm 8,76 \mathrm{IU})$ and the fifth month of lactation $(x=118,90 \pm 8,29 \mathrm{IU}),(\mathrm{p}<0.01)$, as well as in high-pregnant cows $(x=81,33 \pm 3,59 \mathrm{IU})$ compared to cows in the fifth month of lactation $(\mathrm{p}<0.01)$. Our research has not confirmed the connection between the concentration of beta-carotene and vitamin $\mathrm{A}$ in the blood serum of tested cows.
\end{abstract}

Key words: beta-carotene; vitamin A; cows

\section{НИВОТО НА БЕТА-КАРОТИН И ВИТАМИН А ВО КРВЕН СЕРУМ НА СТЕЛНИ И ВИСОКО МЛЕЧНИ КРАВИ ХРАНЕТИ СО РАЗЛИЧНИ СОСТОЈКИ}

\begin{abstract}
Истражувањата беа спроведени на фарма од сименталски крави каде беа формирани 5 групи од 12 крави, кои беа тестирани за концентрација на бета-каротин и витамин А во крвниот серум. Во првата група беа високо стелни крави, а другите четири групи беа од првиот до петтиот месец од доењето.Составот на оброк кај високо бремените и дојните крави во однос на видот и количеството беа различни во одредени хранливи состојки. Во однос на добиените просечни вредности на бета-каротин во крвниот серум, меѓу групите од кравите немаше значајна статистичка разлика. Најниската вредност на бета-каротин во однос на другите групи, беше во серумот на кравите од првиот месец на доењето $(x=3.39 \pm 0.27 \mathrm{mmol} / \mathrm{l})$. Просечната концентрација на витамин А статистички беше значајно пониска за крави во првиот месец од доењето $(x=76.67 \pm 6.39 \mathrm{IU})$, во споредба со крави кои беа во четвртиот $(x=112.03 \pm 8.76 \mathrm{IU})$ и петтиот месец од доењето $(x=118.90 \pm 8.29 \mathrm{IU}),(\mathrm{p}<0.01)$, како и кај високо стелните крави $(x=81.33 \pm 3.59 \mathrm{IU})$ во споредба со кравите во петтиот месец од доењето $(\mathrm{p}<0.01)$. Нашето истражување не ја потврди врската помеѓу концентрацијата на бета-каротин и витамин А во испитуваната крв кај кравите.
\end{abstract}

Клучни зборови: бета-каротин; витамин А; крави

\section{INTRODUCTION}

The meals for cows are often not well balanced and rational, both in terms of choice of nutrients, and in respect of the amounts of certain nutrients and their relationship. A large number of deficency have subclinical character and passes almost unnoticed, but leaves a large economic losses (Jovanović J.M. et al. In 1997, Krnić et al. 2006).

In herds of dairy cows held in our conditions, inadequate supply of vitamin A and beta-carotene is often found even though carotenes are widespread in nature. In plants with the photosynthetic 
activity vitamin A is found mainly in the form of provitamin. For dairy cows a good source of betacarotene and vitamin A is alfalfa, grass, hay, fodder beet leaves. With respect to these nutrients, grain and silage, contain less beta-carotene and vitamin A. A frequent occurrence of hypovitaminosis $\mathrm{A}$, is usually cosequence of large losses of carotene and vitamin A from the nutrients that were stored for a long time and can amount to $90 \%$. They can also be inactivated because of high and low heat, light, UV rays, acid (Veličković et al., 2008). Because of oxidative inactivation of carotene, hay stored for several months loses 40 $80 \%$ of its original carotene content, whereas the loss of carotene in silage is about $30-40 \%$ and it does not become significantly lower during prolonged storage of silage, and it represents an important source of carotene in winter (Jovanović 1984).

It was found that cows with a lower concentration of vitamin A in blood plasma do not utilize effectively beta-carotene, as well as those with normal vitamin A concentration in plasma. Deficit beta-carotene is reversible. This means that fertility, as well as other disorders that are conected to deficits of beta-carotene can be normalized by adding beta-carotene from the alimentary sources (Ivanska and Stravinsky 1997). The role of betacarotene as a precursor for the formation of vitamin A has been known for a long time but, regardless of the role of pro-vitamin, its specific role is established, which is important for the smooth flow of cyclical ovarian activity of cows. (Lotthammer et al 1985). Therefore, in recent decades, beta-carotene again is the subject of many researches, althrough at the same time in the literature the same opinion about the needs of cows for the beta-carotene does not exist (Friesecke 1978, Jovanović 1984, Lotthamuer 1994.1999). Since the concentration of beta-carotene in the blood serum is scientifically acepted as a reliable indicator of the organism supply from the alimentary sources, it is needed to conduct regular analysis of blood parameters of a small number of cows at various stages of production (Veličković 2005, 2008, Vuković 1987, 2005, Ivanov et al . in 2005, Horvat et al., 2007 Šamanc 2010, Radović 2011), which was the goal of our research.

\section{MATERIALS AND METHODS}

The study was conducted at the farm of Simmental cows in July. 60 cows have been tested aged from five to seven years with an average milk production of 5136 liters, divided into five groups of 12 cows. The first group consisted of highly pregnant cows, the second group of cows in the first month of lactation, the third group of cows in the second month of lactation, the fourth group of cows in the fourth month of lactation and the fifth group of cows in the fifth month of lactation. Cows were kept under standard farm conditions. Highpregnant cows diet consisted: $3 \mathrm{~kg}$ alfalfa hay, 15 $\mathrm{kg}$ of maize silage, $15 \mathrm{~kg}$ of beet pulp, $0.07 \mathrm{~kg}$ of mineral addition, $1,93 \mathrm{~kg}$ of concentrate mixture. Lactating cows were fed a meal of $3 \mathrm{~kg}$ of alfalfa hay, $15 \mathrm{~kg}$ of maize silage, $9 \mathrm{~kg}$ brewer's grains, $0.14 \mathrm{~kg}$ of mineral addition, and $3,86 \mathrm{~kg}$ of concentrate mixture.

Blood samples were taken four hours after milking and feeding by puncturing jugular vein into sterile vakutainere. After the spontaneous coagulation of blood at room temperature, blood serum was separated by centrifugation at $3000 \mathrm{rpm}$ for 15 minutes and stored at $-18^{\circ} \mathrm{C}$ until testing. The concentration of beta-carotene and vitamin $\mathrm{A}$ in blood serum was determined by the method of Carr Pricceu principles in the biochemical laboratory Medicus in Kruševac.

The obtained data were statistically analyzed by descriptive statistics and presented in tables. Testing differences in average values of the investigated blood parameters between the groups were performed on the significance level of $p<0.05$ and $\mathrm{p}<0.01$.

\section{RESULTS AND DISCUSSION}

The values of the carotene level in blood of all tested groups of cows were above the lower bound given by Ivanov et al., (2005), and approaching the upper limit of reference interval of $3.79 \mathrm{mmol} / \mathrm{l}$, given by Šamanc (2010) and Radović (2011). We did not observe a statistically significant difference between groups of cows, neihter a considerable variation within groups. In relation to the values quoted by Veličković and Vuković (2005), the values obtained in our study were significantly lower for the highly pregnant cows, and for the cows in the first month of lactation higher. Comparing with the recommendations given by Friesecke (1978), and Lotthammer Winkowski, (1994), we found that the level of carotene in blood of all tested cows had acceptable values.

The average concentration of vitamin A was statistically significantly lower for cows in the first 
month of lactation compared to cows that were in the fourth and fifth month of lactation $(p<0.01)$ II and IV, II and V. This finding can be explained more by taking advantage of vitamin $\mathrm{A}$ for the renewal of the epithelium of reproductive organs in the early puerperium, and its increased excretion via the colostrum (Šamanc, 2010).

Table. 1

Mean value and variability of $\beta$-carrotine content in cow blood serum $(\mu \mathrm{mol} / \mathrm{l})$

\begin{tabular}{ccccc}
\hline \hline Group & $\bar{X} \pm S \bar{x}$ & SD & CV & $\min -\max$ \\
\hline I & $3.63 \pm 0.51$ & 1.25 & 34.42 & $2.01-5.73$ \\
II & $3.39 \pm 0.27$ & 0.66 & 19.58 & $2.68-4.28$ \\
III & $3.73 \pm 0.50$ & 1.23 & 32.98 & $1.95-5.33$ \\
IV & $3.37 \pm 0.54$ & 1.33 & 39.36 & $1.71-5.51$ \\
V & $3.63 \pm 0.71$ & 1.58 & 43.65 & $2.25-6.18$ \\
\hline \hline
\end{tabular}

Relevance NS

Table. 2

Mean value and variability of vitamin A content in cow blood serum (I.U.)

\begin{tabular}{ccccc}
\hline \hline Group & $\bar{X} \pm S \bar{x}$ & SD & CV & $\min -\max$ \\
\hline I & $81.33 \pm 3.59$ & 8.81 & 10.84 & $68.8-91.2$ \\
II & $76.67 \pm 6.93$ & 16.96 & 22.13 & $61.3-107.5$ \\
III & $94.93 \pm 11.06$ & 27.08 & 28.50 & $58.7-128.7$ \\
IV & $112.03 \pm 8.76$ & 21.47 & 19.16 & $87.5-142.5$ \\
V & $118.90 \pm 8.29$ & 18.55 & 15.60 & $90.0-138.8$ \\
\hline \hline
\end{tabular}

Relevence $\mathrm{p}<0,01$ II and IV, II and V, I and IV, I and V

Statistically significantly lower $(p<0.01)$ concentrations of vitamin A were also in highly pregnant cows than in cows in the fourth and fifth month of lactation (I and IV, and V), which can be interpreted by a similar mechanism of action, because the vitamin A is increasingly taken by the mammary glands, and enters the composition of colostrum. Veličković and Vuković (2005), Radović (2011) found a similar trend in the concentration of vitamin A, while the lowest level were found in cows two weeks after birth, or the first month of lactation, which was confirmed in our research.

\section{CONCLUSION}

Based on our research we can conclude that it is not established trend of movement of carotene level in blood during different phases of the reproductive cycle, and not confirmed the connection between movement of carotene level in blood and vitamin A. Concentrations of beta-carotene and vitamin A in blood serum of cows tested were within the physiologic range, which indicates a good supply of these substances through diet for highly pregnant cows, as well as a meal for lactating cows, probably from alfalfa hay.

\section{REFERENCES}

[1] Friesecke H. (1978): Beta-Carotin und die Fruchtbarkeit dis Rindes, Hoffman - La Roche AG, Grenzach - Wyhlem.

[2] Horvat J., Katić Vera, Šamanc H., Kirovski Danijela (2007): Zdravstveni poremećaji visokomlečnih krava u ranoj laktaciji i njihov uticaj na higijensku ispravnos sirovog mleka, VSI Subotica.

[3] Ivanov I., Šamanc H., Vujanac I., Dimitrijević B. (2005): Metabolički profil krava, Zbornik radova 4. simpozijum, Ishrana, reprodukcija i zaštita zdravlja goveda - Etopatogeneza i dijagnostika poremećaja metabolizma reprodukcije goveda, Subotica, 241-247.

[4] Ivanska S., Strusinska D. (1997): The cfect of ß-Carotine and Vitamine $\mathrm{A}, \mathrm{D}_{3}$ and $\mathrm{E}$ on Scme Reproductive $\mathrm{Pa}$ rameters in Cows, Acta Veternaria Hungarica, 15 (1), 95-107.

[5] Jovanović M. (1984): Fiziologija domaćih životinja, Beograd - Zagreb.

[6] Jovanović M., Rajić I., Pešterac V., Črčev D., Čokrevski S. (1997): Parametri krvi visoko steonih i tek oteljenih krava hranjenih obrocima različitog sastava, Veterinarski glasnik, 51, 5-6, 231-244.

[7] Krnić J., Eva Rašić Juhas, Kanački Z., Aida Hodžić, Hamandžić M. (2006): Uticaj nepovoljnih uslova ishrane na karakteristike metaboličkog profila krava, Savremena poljoprivreda, vol. 55, 3-4, 136-142.

[8] Lotthammer K. H. (1985): Ursachem und Massnahmen beim primar nicht infektiosen genitalkatarrh des Rindes. Prakt. Tierarzt. 66, 79-84.

[9] Lotthammer K. H., Winkowski G. (1994): Fruchtbarkeit und Gesundheit dis Rindes, Verlag Eule.

[10] Lotthammer K. H. (1999): Klinisch - chemische Untersuchungen bei bestandweise auffretenden Fruchbarketsstorungen. In: E. Grunert. A. De Kruif (Hrsg): Fruchbarkeitsstorungen beim weiblichen Rind. Perey Buchverlag, Berlin. 
[11] Radović Bisa, Jotanović Stoja, Savić Đ., Nitovski A. (2011): Biohemijski parametri krvi krava simentalske rase u različitim fazama reproduktivnog ciklusa, Veterinarski glasnik, 65, 3-4, 191-200.

[12] Veličković M., Vuković D. (2005): Koncentracija betakarotina i vitamina A u krvnom serumu krava u peripartalnom periodu, Veterinarski glasnik, 59, 5-6, 557-567.

[13] Veličković M., Vuković D. (2008): Uticaj parenteralne aplikacije beta-karotina na plodnost krava, Veternarski glasnik, 62, 1-2, 53-56.
[14] Vuković D., Šamanc H., Damjanović Z., Perković S., Ignjić Đ. (1987): Koncetracija Ca, P, karotina i vitamina A u krvnom serumu krava simentalske rase sa osvrtom na poremećaj plodnosti, Veterinarski glasnik, 41, 11-12, 927-930.

[15] Šamanc H. (2010): Bolesti organa za varenje goveda, Naučna KMD, Beograd.

[16] Šamanc H., Sinovec Z., Adamović M., Grubić G. (2005): Uloga ishrane u etiopatogenezi poremećaja metabolizma visoko mlečnih krava, IV Simpozijum „Ishrana, reprodukcija i zaštita zdravlja goveda ", Zbornik radova, 3-20. 